\author{
Maria Reisky \\ ORCID: 0000-0002-0626-714X \\ Uniwersytet Opolski
}

\title{
Polski kryzys na forum Bundestagu w 1980 roku
}

DOI: $10.19195 / 1643-0328.27 .7$

Słowa kluczowe: Bundestag, stosunki polsko-niemieckie, VIII i IX kadencja, kredyty, mniejszość niemiecka, kryzys

\section{Wprowadzenie}

Latem 1980 roku rozpoczął się w Polsce okres gwałtownych przemian, które stały się przedmiotem obserwacji, analizy i dyskusji w wielu państwach europejskich. W Republice Federalnej Niemiec temat Polski i zarysowującego się coraz wyraźniej kryzysu gospodarczego, politycznego oraz społecznego był przedmiotem dyskusji politycznych prowadzonych zarówno w prasie zachodnioniemieckiej, jak i Bundestagu.

Cezura artykułu obejmuje zaledwie jeden rok — od stycznia do grudnia 1980, kiedy to zakończyła się czteroletnia VIII kadencja Bundestagu (1976-1980), a także doszło do wyborów parlamentarnych i rozpoczęła się IX kadencja (1980-1983). Omawiany okres należy podzielić na dwie zasadnicze części: pierwsza z nich to czas od stycznia do lata 1980, druga zaś - od lata do grudnia 1980 roku. Taki podział narzucił nie tylko kalendarz wyborczy, lecz także tematyka dyskusji na forum Bundestagu. Pierwsza połowa roku upłynęła $\mathrm{w}$ miarę spokojnie i zasadniczo nie odbiegała $\mathrm{w}$ relacjach polsko-niemieckich od okresów wcześniejszych. W parlamencie poruszano przede wszystkim temat polskiego kryzysu gospodarczego oraz ewentualnej pomocy kredytowej udzielanej przez RFN. Posłowie skupiali się również na sprawach mniejszości niemieckiej zamieszkującej Polskę, niejednokrotnie włączając do dyskusji kwestię łączenia rodzin. Kolejnym tematem był problem realizacji zaleceń podręcznikowych dla obu państw. Natomiast druga połowa roku charakteryzowała się wzmożonym zainteresowaniem wydarzeniami w Polsce, które były związane z powstaniem „Solidarności”, kwestią kryzysu gospodarczego i pomocy kredytowej oraz grożącym zagrożeniem interwencji ZSRR w Polsce. To właśnie wydarzenia drugiej połowy 1980 roku są tematem wiodącym niniejszego opracowania. Wydarzenia polskie wywołały bowiem duże zainteresowanie w kręgach politycznych i stały się ciekawym elementem dyskusji w Bundestagu. Nałożyły się w do- 
datku na niezwykle emocjonującą kampanię wyborczą do Bundestagu IX kadencji (lato $1980 \mathrm{roku}$ ), co znacznie wpłynęło na postrzeganie spraw polskich na arenie zachodnioniemieckiej. Temat polskiego kryzysu stał się częścią zaciętej kampanii, w której sprawa polska niejednokrotnie stawała się przedmiotem gry wyborczej.

Jak często poruszano temat Polski na forum Bundestagu? W jaki sposób relacjonowano sytuację nad Wisłą? Kto najczęściej zabierał głos i jakie postulaty wysuwał? Nad jakimi kwestiami dyskutowano? Aby odpowiedzieć na wskazane pytania, analizie poddano protokoły plenarne posiedzeń Bundestagu VIII oraz IX kadencji, analizę uzupełniając o komentarze z wybranych tytułów prasy zachodnioniemieckiej.

$\mathrm{Na}$ temat stosunków polsko-niemieckich powstało wiele różnorodnych tematycznie prac autorów zarówno polskich, jak i niemieckich, spośród których można wymienić między innymi: Piotra Madajczyka ${ }^{1}$, Małgorzatę Świder ${ }^{2}$, Annę Wolff-Powęską czy Dietera Bingena ${ }^{4}$. Niewiele opracowań naukowych dotyka jednakże samej kwestii polskiej na forum Bundestagu lub analizy stosunków polsko-niemieckich na podstawie protokołów z jego posiedzeń. Wyjątkiem są opracowania Aleksandry Trzcielińskiej-Polus ${ }^{5}$. Natomiast polskojęzyczna literatura dotycząca tematyki Bundestagu, jego funkcjonowania oraz organizacji jest dość skąpa ${ }^{6}$; nieporównanie większą liczbą opracowań w tym zakresie tematycznym może się pochwalić historiografia niemieckojęzyczna ${ }^{7}$.

${ }^{1}$ P. Madajczyk, Marzenie o narodzie doskonalym. Między biopolityka a etnopolityka, Warszawa 2017; idem, Na drodze do pojednania: wokół orędzia biskupów polskich do biskupów niemieckich z 1965 roku, Warszawa 1994; idem, Niemcy polscy 1944-1989, Warszawa 2001.

2 M. Świder, „Wann werden die Sowjets in Polen einmarschieren?”. O groźbie interwencji sowieckiej w Polsce 1980-1982. Widziane z Bonn, [w:] O Polskę wolną! O Polskę solidarną! NSZZ Solidarność w latach 1980-1989, red. W. Polak et al., Gdańsk 2011; eadem, Sierpień 1980 - zaskoczenie czy spodziewany wybuch? Konflikt społeczno-polityczny w Polsce w ocenach dziennikarzy zachodnioniemieckich, „Studia Zachodnie” 2010, nr 12; eadem, Bońskie spojrzenie na polski sierpień, [w:] Czas Przełomu. Solidarność 1980-1981, red. W. Polak et al., Gdańsk 2010.

3 A. Wolff-Powęska, Polen in Deutschland: Integration oder Separation?, Düsseldorf 2000; eadem, Polacy wobec Niemców. Z dziejów kultury politycznej Polskiej Rzeczypospolitej Ludowej 1945-1989, Poznań 1993; eadem, Doktryna geopolityki w Niemczech, Poznań 1979.

4 D. Bingen, H. Wagner, Die ,deutsche Ostpolitik” in der Sicht ihrer Erfinder, „Rocznik Polsko-Niemiecki" 13, 2005; D. Bingen, Ostpolitik und demokratischer Wandel in Mittel- und Osteuropa. Der Testfall Polen, „Archiv für Sozialgeschichte” 45, 2005; idem, Kontinuität und Wandel. Die Bonner Polenpolitik von den Anfangsjahren bis zum Freundschaftsvertrag von 1991, [w:] Erlebte Nachbarschaft. Aspekte der deutsch-polnischen Beeziehungen im 20. Jahrhundert, red. J.P. Barbian, M. Zybura, Wiesbaden 1999; idem, Polityka Republiki Bońskiej wobec Polski. Od Adenauera do Kohla. 1949-1991, Kraków 1997.

5 Zob. między innymi A. Trzcielińska-Polus, Współkształtowanie polityki zagranicznej Niemiec przez Bundestag, [w:] Polityka zagraniczna zjednoczonych Niemiec: kontynuacja czy zmiana?, red. I.P. Karolewski, Wrocław 2011; eadem, Pomoc RFN dla Polski i Polaków w latach 1980-1983 (na podstawie dokumentów Bundestagu IX kadencji), [w:] Polityka i humanitaryzm. 1980-1989, red. M. Świder, Toruń 2010; eadem, Polska na forum Bundestagu (1990-2002). Współkształtowanie przez Parlament Związkowy polityki zagranicznej Niemiec w kontekście procesu integracji europejskiej, Opole 2008.

${ }^{6}$ O Bundestagu pisali między innymi J. Isensee, P. Kirchhof, Parlament Republiki Federalnej Niemiec, Warszawa 1995; K.A. Wojtaszczyk, Bundestag i Bundesrat w Republice Federalnej Niemiec, Warszawa 1993; L. Garlicki, Parlament a rzad w Republice Federalnej Niemiec, Wrocław 1978; idem, Ustrój polityczny Republiki Federalnej Niemiec, Warszawa 1985.

${ }^{7}$ Literatura niemieckojęzyczna dotycząca Bundestagu jest niezwykle obszerna; zob. na przykład V. Stalmann, Die FDP-Fraktion im Deutschen Bundestag, Düsseldorf 2017; W. Ismayr, Der Deutsche Bundestag. 
Zanim przeanalizowana zostanie problematyka polskiego kryzysu na forum Bundestagu, należy krótko omówić stosunek posłów zachodnioniemieckich do Polski w 1980 roku, przy czym trzeba zaznaczyć, że PRL nie stanowiła dla RFN najważniejszego punktu w relacjach $\mathrm{z}$ blokiem wschodnim. Bez wątpienia kwestią priorytetową dla RFN były stosunki z NRD, a następnie ze Związkiem Radzieckim. Dodatkowo niektórzy zachodnioniemieccy politycy widzieli $\mathrm{w}$ powstaniu „Solidarności” i protestach na polskim wybrzeżu zagrożenie dla i tak już skomplikowanej europejskiej polityki odprężenia. Postrzeganie sprawy polskiej doprowadziło do wielu dyskusji w Bundestagu, a także uwidoczniło różne stanowiska partii politycznych w tej kwestii. Partie współrządzące - SPD oraz FPD - wyrażały nadzieję na szybkie i pokojowe zakończenie konfliktu między władzami PRL a robotnikami; powstrzymywały się przy tym od komentarzy, nie chcąc, aby rząd niemiecki został posądzony o wtrącanie się w sprawy wewnętrzne jednego z państw bloku wschodniego. Najbardziej jednak zależało im na utrzymaniu pokoju w Europie i kontynuowaniu polityki odprężenia, a przede wszystkim na niepogarszaniu relacji niemiecko-niemieckich. Z kolei posłowie CDU oraz CSU otwarcie wyrażali swoje opinie (głównie popierając protesty w Polsce), ponieważ nie musieli zachowywać ostrożności dyplomatycznej, która obowiązywała koalicję rządzącą ${ }^{8}$. Było to szczególnie widoczne podczas obrad Bundestagu9. Wówczas posłowie, wykorzystując dozwolone zasady gry parlamentarnej, mogli dać wyraz własnym poglądom — przykładowo, mogli żądać wyjaśnień rządu w kwestiach spornych bądź kontrowersyjnych, wnosząc tym samym interesujący ich temat do świadomości publicznej ${ }^{10}$.

\section{Sprawa polska na forum Bundestagu VIII kadencji}

Dla władz w Bonn najistotniejszymi tematami poruszanymi na forum Bundestagu na początku 1980 roku tradycyjnie już były kwestia praw mniejszości niemieckiej w Polsce oraz sprawy stosunków gospodarczych - głównie w kontekście udzielania kredytów i polskiego zadłużenia. Ciekawym elementem okazał się temat podręczników szkolnych, co wynikało z inicjatywy Helmuta Schmidta oraz Edwarda Gierka dotyczącej powołania w 1972 roku polsko-niemieckiej komisji podręcznikowej.

Funktionen, Willensbildung, Reformansätze, Wiesbaden 2012; M.F. Feldkamp, Der Deutsche Bundestag 100 Fragen und Antworten, Baden-Baden 2009; Der Deutsche Bundestag im Reichstagsgebäude, red. M. Reinold, Ch. Beinke, Berlin 2007; Fakten: der Bundestag auf einen Blick, red. H.W. Schors, K. Vogel, Berlin 2006; W. Ismayr, Der Deutsche Bundestag im politischen System der Bundesrepublik Deutschland, Opladen 2000; C. Kaiser, W. Kessel, Deutscher Bundestag 1949-1999, München 1999; R. Schick, W. Zeh, So arbeitet der deutsche Bundestag: Organisation und Arbeitsweise. Die Gesetzgebung des Bundes, Bad Honnef 1999.

${ }^{8}$ D. Bingen, Polityka Republiki Bońskiej..., s. 193-194.

${ }^{9}$ K.A. Wojtaszczyk, op. cit., s. 17.

10 Można tego dokonać na kilka sposobów, przy czym najbardziej klasycznym są zapytania poselskie. Regulamin Bundestagu rozróżnia duże zapytania (große Anfragen), nazywane interpelacjami, oraz małe zapytania (kleine Anfragen). Posłowie uprawnieni są także do zadawania pojedynczych pytań poselskich (Einzelfragen) $\mathrm{w}$ formie ustnej lub pisemnej oraz podczas „godzin pytań” (Fragestunde) - A. Trzcielińska-Polus, Polska na forum..., s. 64, 66, 70. 
Kwestia problemu mniejszości niemieckiej w Polsce zaczęła pojawiać się coraz częściej, jako że w PRL rozpoczął się okres przemian społeczno-politycznych, co zaktywizowało również środowiska mniejszościowe. Temat ten stał się stałym elementem rozmów polsko-niemieckich, w związku z czym prawa mniejszości niemieckiej stały się często omawianym wątkiem na forum Bundestagu ${ }^{11}$.

Do równie problematycznych tematów w relacjach bilateralnych należały kwestie związane z podtrzymywaniem tradycji i kultury niemieckiej. Do pierwszej dyskusji na ten temat doszło w styczniu 1980 roku. Wywiązała się wówczas polemika między posłem chadecji oraz prezesem Związku Wypędzonych w latach 1970-1994, Herbertem Czają, a posłanką FPD, ministrem stanu, Hildegard Hamm-Brücher. Tematem była konferencja dwustronna przygotowywana wspólnie przez RFN i PRL. Konferencja była efektem podpisania aktu kończącego Konferencji Bezpieczeństwa i Współpracy w Europie z 1975 roku. Czaja domagał się odpowiedzi na pytanie, czy podczas obrad konferencji zostanie poruszona kwestia utrzymania zakazu dyskryminacji oraz gwarancji zachowania wartości kulturalnych i narodowych dla Niemców zamieszkujących tereny na wschód od Odry i Nysy ${ }^{12}$.

Kolejnym elementem relacji polsko-niemieckich odnoszących się do problemów mniejszościowych było postulowane przez RFN zezwolenie mniejszości niemieckiej na organizowanie się w grupach, wydawanie gazet w języku niemieckim, uczestniczenia w niemieckojęzycznych nabożeństwach i mszach świętych, a także zorganizowanie zajęć szkolnych w języku niemieckim ${ }^{13}$. Na forum Bundestagu kwestię tę podnosił niejednokrotnie Herbert Czaja mocno związany z organizacjami mniejszościowymi. W jego opinii Ministerstwo Spraw Zagranicznych powinno skompletować odpowiednią dokumentację mającą świadczyć o dyskryminowaniu Niemców w Polsce ${ }^{14}$.

Posłowie odnosili się także do kwestii związanych z polsko-niemieckimi wizytami rodzinnymi. Był to dość poważny problem, zważywszy, że liczba wyjazdów „legalnych” była znacznie mniejsza niż liczba wyjazdów „nielegalnych”, to znaczy na podstawie tak zwanej wizy turystycznej (mowa tu o stosunku 10 tysięcy do 40 tysięcy). Coraz większa liczba obywateli polskich pozostawała bowiem na Zachodzie, korzystając z prawa do odwiedzin rodziny w RFN. Tworzyło to wiele nowych problemów, między innymi komplikowało akcję łączenia rodzin i mogło naruszyć stabilność stosunków polsko-niemieckich ${ }^{15}$.

Temat wyjazdów pojawił się również na forum Bundestagu. Posłowie chadecji, z Czają na czele, zastanawiali się, czy Polska przestrzega zobowiązań przyjętych w grudniu $1970 \mathrm{roku}^{16}$, skoro zezwolenie na wizytę rodzinną w Niemczech uzyskuje tylko je-

${ }^{11}$ M. Świder, Oficjalne deklaracje i zakulisowe gry. Problem mniejszości niemieckiej w Polsce pod koniec lat osiemdziesiątych, [w:] Upadek systemu komunistycznego na Górnym Śląsu. Wokót przemian 1989 roku w województwach katowickim i opolskim, red. A. Dziuba, S. Rosenbaum, Katowice 2010, s. 355.

12 Plenarprotokoll 8/197 Sitzung, 18.01.1980, s. 15681.358.

13 M. Świder, Oficjalne deklaracje..., s. 358.

14 Plenarprotokoll 8/197 Sitzung, 18.01.1980, s. 15681.

15 M. Świder, Oficjalne deklaracje..., s. 358.

16 Chodzi tutaj o układ PRL-RFN z 7 grudnia 1970 roku, w którym strony postanowiły kierować się w stosunkach zasadami Karty Narodów Zjednoczonych oraz zobowiązały się podejmować kroki zmierzające do pełnej normalizacji i wszechstronnego rozwoju wzajemnych stosunków w dziedzinach gospodar- 
den członek rodziny z Polski. Ustalono jednak, że strona polska stosowała tę praktykę również wobec innych krajów Europy Zachodniej. Równocześnie zaznaczono, iż liczba polskich zezwoleń na wizyty rodzinne wzrosła z 45 tysięcy w 1975 do ponad 202 tysięcy w 1979 roku. Miało to świadczyć o dobrej woli władz PRL, z którymi prowadzono rozmowy w sprawie zwiększenia limitu wyjazdów do $\mathrm{RFN}^{17}$. Równocześnie rząd RFN starał się wskazać władzom w Warszawie zależność między wyjazdami a sytuacją mniejszości w Polsce. Próbowano przekonać stronę polską, że polepszenie warunków życia mniejszości niemieckiej znacząco zmniejszy liczbę osób składających wniosek o wyjazd.

Inną kwestią związaną z polsko-niemieckimi rozmowami były zalecenia podręcznikowe. Aby ograniczyć liczbę sporów w tym temacie, powołano komisję podręcznikową złożoną z 20 polskich i niemieckich naukowców (głównie historyków i geografów) ${ }^{18}$. Jej zadaniem było ustalenie stanowisk zarówno Polski, jak i RFN w sprawach, w których dochodziło dotąd do różnicy poglądów, a znajdujących odzwierciedlenie w treści podręczników szkolnych do historii i geografii obowiązujących w obu krajach ${ }^{19}$. Posłowie Bundestagu, między innymi z SPD: Klaus von Dohnanyi, Frolinde Balser, Helmuth Becker, oraz posłowie chadecji: Herbert Czaja, Herbert Hupka i Helmut Sauer, niejednokrotnie dyskutowali na temat podręczników szkolnych oraz ich wad i potrzebnych zmian. Między innymi poseł SPD Klaus von Dohnanyi zauważył, że po obu stronach podręczniki wykazywały wiele braków. Dlatego też, zadaniem rządu zachodnioniemieckiego, należało wesprzeć inicjatywę wypracowania zaleceń, u której podstaw miało stać wzajemne zrozumienie i położenie podstaw pod pokojowe relacje oraz lepszą edukację młodzieży ${ }^{20}$.

Jednym z głównych tematów poruszanych na forum Bundestagu, zarówno w pierwszej, jak i drugiej połowie 1980 roku, były kwestie gospodarcze oraz narastające zadłu-

czych, naukowo-technicznych, kulturowych i innych. Zob. N. Jackowska, Układ z 1970 roku o podstawach normalizacji stosunków z RFN: przypadek ponadpolitycznej zgody?, „Studia Politologica” 5, 2011, s. 144-157.

17 Plenarprotokoll 8/215 Sitzung, 25.04.1980, s. 17210-17211.

18 Więcej o działaniach komisji podręcznikowej pisze K. Ruchniewicz, Enno Meyer a Polska i Polacy (1939-1990). Z badań nad początkami Wspólnej Komisji Podręcznikowej PRL-RFN, Wrocław 1994.

19 Komisja została utworzona w 1972 roku pod auspicjami UNESCO. W jej skład wchodzili między innymi: Georg Eckert, Hans-Adolf Jacobsen i Janusz Tazbir. Do 1976 roku komisja odbyła dziewięć posiedzeń, z których po dwóch pierwszych (w Warszawie i Brunszwiku) opublikowano łącznie 31 kluczowych wówczas zaleceń; zob. Zalecenia Komisji UNESCO Polskiej Rzeczypospolitej Ludowej i Republiki Federalnej Niemiec do spraw Podręczników Szkolnych w Zakresie Historii i Geografi, http://deutsch-polnische.schulbuchkommission.de/fileadmin/_dpsk/Bild/Zaleceni_1972.pdf (dostęp: 10.11.2018); por. J. Klepacka, Wspólna przeszłość - wspólny podręcznik?, „Polski Kalendarz Europejski” 2009, nr 123, s. 36.

20 Co ciekawe, w trakcie obrad w Bundestagu pojawiły się głosy, między innymi posła Herberta Hupki, że to strona polska opóźniała prace nad tworzeniem i realizowaniem zaleceń podręcznikowych. W trakcie dyskusji przytoczona została także opinia jednego z naukowców, prof. Alfreda Grossera, niemiecko-francuskiego publicysty oraz politologa, który stwierdzał, iż podręcznikowe określenie „przesunięcia ludnościowe", używane w kontekście przymusowych wysiedleń Niemców, jest ograniczone, niedokładne oraz zbyt łagodne. Co do błędnego nazewnictwa przesiedleń Niemców koalicja, na czele z posłem SPD Klausem von Dohnanyi, pozostawała przy nazywaniu przesiedleń przesunięciami, gdyż - jak uważano - nie wszystkich Niemców przesiedlono. Kwestia ta wzbudzała ogromne emocje wśród posłów. Zob. Plenarprotokoll 8/211 Sitzung, 17.04.1980, s. 16897-16901. 
żenie Polski. Na początku lat osiemdziesiątych nastąpiło w Polsce gwałtowne załamanie gospodarcze. PRL była już zadłużona na 24,1 miliarda dolarów i zalegała ze spłatami kredytów. Państwa zachodnie ustosunkowywały się coraz bardziej negatywnie do wniosków kredytowych dla Polski ${ }^{21}$. Już od lutego 1980 roku w prasie RFN pojawiały się artykuły poświęcone sytuacji kryzysowej w państwie polskim ${ }^{22}$. W opinii zachodnioniemieckich dziennikarzy wybuch protestów był kwestią czasu. Na początku sierpnia 1980 roku wzrosła liczba doniesień prasowych mówiących o krytycznej sytuacji gospodarczej i społecznej nad Wisłą ${ }^{23}$. Również posłowie Bundestagu omawiali problemy gospodarcze Polski. Podczas styczniowego posiedzenia Bundestagu głos w tej sprawie zabrał sekretarz stanu oraz polityk FPD Martin Grüner, który przypomniał, że zobowiązania rządu zachodnioniemieckiego $\mathrm{z}$ tytułu poręczeń udzielanych państwom bloku wschodniego wynosiły 16,4 miliarda marek, $\mathrm{z}$ czego Polska oraz ZSRR zajmowały w tym rankingu miejsca w czołówce ${ }^{24}$.

Na tle tematu pomocy gospodarczej doszło do wielu wewnętrznych starć. Dyskutowano na temat wielkości kredytów oraz celów, na jakie miały one zostać w Polsce przeznaczone. Między innymi sekretarz stanu Grüner wspomniał o wizycie ministra Ottona Lambsdorffa ${ }^{25}$ w Polsce, którą złożył 7 marca 1980 roku. Podczas spotkania z wiceministrem handlu zagranicznego Stanisławem Długoszem ${ }^{26}$ Lambsdorff zagwarantował gotowość przejęcia przez RFN poręczeń na dostawy eksportowe wyrobów stalowych, włókien syntetycznych, chemikaliów oraz części zamiennych i komponentów do Polski w 1980 roku w wysokości 500 milionów marek w ramach tak zwanego Hermesbürgschaften, czyli ubezpieczenia kredytowego niemieckich transakcji eksportowych.

Wsparcie polskiej gospodarki, szczególnie wydobycia surowców, wydawało się niemieckim politykom koalicji drogą do sukcesu finansowego w późniejszych latach, przyczyniłoby się także do zabezpieczenia dostaw ważnych surowców do RFN. To właśnie

21 J. Skodlarski, Zarys historii gospodarczej Polski, Warszawa 2000, s. 484.

22 C.G. Ströhm, Parteitag der Surrealisten, „Die Welt” 13.02.1980; Vorsichtiger Vorstoß, „Frankfurter Rundschau” 13.02.1980; Der Konferenz-Trick, „Frankfurter Allgemeine Zeitung” (dalej: FAZ) 13.02.1980; J. Riedmiller, Edward Giereks neue Abrüstungs-Offerte, „Süddeutsche Zeitung” (dalej: SZ) 13.02.1980.

23 Solidarność związkowa. Niemiecka Federacja Związków Zawodowych (DGB) wobec NSZZ „Solidarność", wybór, wstęp i oprac. M. Świder, Kraków 2017, s. 49.

24 Plenarprotokoll 8/197 Sitzung, 18.01.1980, s. 15743.

25 Otto Graf Lambsdorff (1926-2009) - niemiecki polityk FDP, minister. Od 7 października 1977 do 17 września 1982 roku był ministrem gospodarki i technologii w drugim i trzecim rządzie Helmuta Schmidta; 4 października powrócił na stanowisko ministra w nowym rządzie Helmuta Kohla. Stanowisko zachował również w następnym rządzie Kohla (1983), ale 24 czerwca 1984 roku - w wyniku tak zwanej afery Flicka - podał się do dymisji. Od 1988 do 1993 roku był przewodniczącym FDP; zob. Otto Graf Lambsdorff gestorben, https://www.welt.de/politik/article5442764/Otto-Graf-Lambsdorff-gestorben.html (dostęp: 9.11.2018).

26 Stanisław Długosz (1925-2019) - polski polityk, doktor nauk ekonomicznych. W 1972 roku został wiceministrem handlu zagranicznego. W okresie od października 1980 do grudnia 1988 roku był zastępcą przewodniczącego Komisji Planowania przy Radzie Ministrów. Uczestniczył w obradach Okrągłego Stołu w podzespole do spraw gospodarki i polityki społecznej; zob. T. Mołdawa, Ludzie władzy 1944-1991, Warszawa 1991. 
polskie rezerwy surowcowe stały się głównym powodem udzielenia pomocy Polsce ${ }^{27}$. Argumentem przemawiającym za udzieleniem pomocy kredytowej przez RFN (to podniósł między innymi Grüner) był czynny udział innych państw zachodnich w akcji wsparcia gospodarki polskiej. Zachodnie kraje przemysłowe przewyższały RFN w wysokości udzielonych Polsce pożyczek. Ryzyko niepowodzenia tej akcji było więc dla wszystkich krajów takie samo. Większość parlamentarna wierzyła, że polski kryzys ograniczy się do lat 1980-1981, potem PRL zwalczy problemy i rozpocznie proces wyjścia z zadłużenia, co dla RFN miało z kolei procentować zyskami, szczególnie w obszarze handlu zagranicznego $^{28}$. Innego zdania w tej kwestii była chadecja. Herbert Czaja uważał, że przyjmując na siebie tak duże obciążenie, gospodarka niemiecka mogła znaleźć się w stanie zagrożenia. Argumentował i ostrzegał, że polskie zadłużenia rosły nadmierne, a próba opanowania klęski finansowej w tym kraju zakończy się niepowodzeniem. Rządzącym zarzucał, że pomimo ogromnego zadłużenia RFN nadal wspiera finansowo PRL. Żądał ponadto zapewnienia, że $w$ razie pogłębienia polskiego kryzysu Republika Federalna pozostanie zabezpieczona przed utratą zainwestowanych pieniędzy. Obawiał się również, że podjęcie złej decyzji w tej sprawie oraz zatrważający brak zdolności kredytowej Polski doprowadzi do ruiny niemieckiego podatnika ${ }^{29}$.

Pomimo początkowo nieprzychylnej oceny kwestii przyznawania Polsce kolejnych kredytów ostatecznie decyzja ta została rozpatrzona pozytywnie. Głównym argumentem przemawiającym za udzieleniem kredytu był ich cel, mianowicie wparcie przede wszystkim górno- i dolnośląskich przedsiębiorstw. Herbert Hupka z CDU, równocześnie pełniący funkcję przewodniczącego Ziomkostwa Śląsk (1968-2000) i wiceprzewodniczącego Związku Wypędzonych, wypowiedział przy tym dość kontrowersyjną opinię, że Śląsk wprawdzie znajdował się na „obszarze w posiadaniu polskim”, ale jego sytuacja prawna nie była do końca wyjaśniona ${ }^{30}$. Stwierdzenie to wywołało oburzenie środowisk politycznych w Polsce, gdyż przeczyło postanowieniom układu PRL-RFN z grudnia 1970 roku o uznaniu granicy wschodniej z Polską oraz niekwestionowaniu istniejącego stanu prawnego $^{31}$. Drugim ważnym argumentem było zamieszkiwanie tych terenów głównie przez mniejszość niemiecką. Chadecja, a szczególnie politycy związani ze Związkiem Wypędzonych ${ }^{32}$, postulowali uzależnienie kwestii kredytowo-gospodarczych od zgody na wyjazd obywateli niemieckich żyjących na terenie Polski w ramach wspomnianej już

27 Plenarprotokoll 8/207 Sitzung, 19.03.1980, s. 16590.

28 Plenarprotokoll 8/216 Sitzung, 13.05.1980, s. 17336.

29 Plenarprotokoll 8/216 Sitzung, 13.05.1980, s. 17335.

30 Plenarprotokoll 8/211 Sitzung, 17.04.1980, s. 16894.

31 Zob. układ między Polską Rzecząpospolitą Ludową a Republiką Federalną Niemiec o podstawach normalizacji ich wzajemnych stosunków, podpisany w Warszawie dnia 7 grudnia 1970 roku, http://prawo. sejm.gov.pl/isap.nsf/download.xsp/WDU19720240168/O/D19720168.pdf (dostęp: 11.11.2018).

32 Związek Wypędzonych (niem. Bund der Vertriebenen) - niemiecka organizacja utworzona 27 listopada 1957 roku przez połączenie Zjednoczenia Ziomkostw (Vereinigung der Landsmannschaften) i Związków Wypędzonych Niemców (Bund vertriebener Deutscher), skupiająca osoby narodowości niemieckiej wysiedlone w konsekwencji postanowień konferencji poczdamskiej z byłych terenów niemieckich Polski i ZSRR oraz z terytorium Czechosłowacji po zakończeniu drugiej wojny światowej, a także osoby ewakuowane lub zbiegłe przed Armią Czerwoną, tak zwanych późnych przesiedleńców (Spätaussiedler), czyli 
akcji łączenia rodzin. W tej sprawie apelował także poseł CDU Manfred Wörner, który stwierdzał, że obowiązkiem rządu jest i będzie powiązanie kwestii jakiejkolwiek pomocy Polsce z rozpatrzeniem wniosków przesiedleńców, którzy chcą opuścić ten kraj ${ }^{33}$.

Ostatnie posiedzenie plenarne Bundestagu VIII kadencji miało miejsce 4 lipca 1980 roku ${ }^{34}$.

\section{Obrady posłów Bundestagu IX kadencji}

Lato to czas urlopów i zawieszenia posiedzeń, co nie oznacza, że politycy niemieccy nie interesowali się wydarzeniami w Polsce, a Bundestag nie pracował. Na okres ten przypadają bowiem kampania wyborcza i wybory do Bundestagu, w których kwestie polskie odegrały ważną rolę. Okoliczności wyborów w 1980 roku były diametralnie różne od poprzednich kampanii wyborczych, albowiem latem 1980 nasilony kryzys gospodarczy i polityczny w Polsce doprowadził do wybuchu strajków, a następnie powstania "Solidarności". Wydarzenia te miały znaczący wpływ na toczącą się walkę wyborczą, gdyż stały się swoistą kartą przetargową ${ }^{35}$.

Istotnym elementem kampanii SPD stały się wizyty dyplomatyczne. Dotyczyły one przede wszystkim relacji RFN-NRD, głównie w kontekście planowanej wizyty kanclerza Helmuta Schmidta w NRD. Kolejnym argumentem, który miał zapewnić kanclerzowi większe poparcie wyborcze, była planowana na lato 1980 roku wizyta Edwarda Gierka w Hamburgu. Obie te wizyty, a także spotkanie Schmidta w Moskwie, były elementami polityki wschodniej prowadzonej wspólnie przez koalicję SPD i FPD. Opozycja niejednokrotnie wykorzystywała fakt, iż obie te wizyty początkowo zostały tylko przełożone, jednak w wyniku niebezpiecznego rozwoju sytuacji w Polsce Gierek ostatecznie postanowił odwołać swoją wizytę ${ }^{36}$. Według dziennikarza „Frankfurter Rundschau” Dietera Schrödera planowane spotkanie na szczycie w zamyśle Gierka miało na celu pokazanie rodakom politycznego i finansowego poparcia Zachodu dla Polski ${ }^{37}$. Powagę tej sytuacji zauważyły również inne zachodnioniemieckie tytuły, zastanawiając się, czy do spotkania jeszcze kiedyś dojdzie ${ }^{38}$. Odwołana wizyta Gierka miała też wpływ na wewnętrzną

osoby, które zadeklarowały narodowość niemiecką i wolę wyjazdu do RFN po 1 stycznia 1993 roku. Zob. oficjalna strona Związku Wypędzonych, http://www.bund-der-vertriebenen.de.

33 Plenarprotokoll 9/6 Sitzung, 26.11.1980, s. 101.

34 Plenarprotokoll 8/230 Sitzung, 4.07.1980.

35 M. Świder, Wplyw polskiego sierpnia na niemiecki październik 1980 roku, [w:] Trudne sąsiedztwo. $Z$ dziejów relacji polsko-niemieckich w XX i początkach XXI wieku, red. K. Jedynakiewicz-Mróz, Wrocław 2011, s. 64-65.

${ }^{36}$ M. Świder, Stanowisko Socjaldemokratycznej Partii Niemiec wobec Polski w latach 1980-1989, Opole 2015, s. 91-94.

37 D. Schröder, Machtprobe mit Gierek, „Süddeutsche Zeitung” 19.08.1980.

38 Streiks in Polen - gegen die Partei, „Der Spiegel” 18.08.1980; Gierek: Wir haben Fehler gemacht. Treffen mit Kanzler Schmidt abgesagt, "Rheinische Post” 19.08.1980; Gierek in Not, "General-Anzeiger” 19.08.1980; Zuspitzung in Polen, „Der Tagesspiegel” 19.08.1980; Forderungen an die Führung, „Frankfurter 
walkę w RFN, między innymi stała się powodem do zaatakowania kanclerza Schmidta. Opozycja parlamentarna w Bundestagu i niektóre gazety odczytały bowiem odwołanie wizyty Gierka jako niepowodzenie polityki zagranicznej Schmidta. Kanclerzowi zarzucono brak inicjatywy, uważano, że nie powinien był czekać, aż Gierek odwoła wizytę, i wcześniej uzgodnić z nim przesunięcie terminu spotkania ze względu na niepokoje wśród polskich robotników. Dodatkowo sądzono, że kanclerz RFN powinien wstrzymać pomoc finansową dla Polski do czasu uzyskania pewności, że wobec polskich robotników nie zostanie użyta siła ${ }^{39}$.

Temat polski przewijał się wielokrotnie w dyskusjach w trakcie kampanii wyborczej i polaryzował zarówno polityków, jak i wyborców. Ostatecznie w wyborach z 5 października 1980 roku zwyciężyła koalicja SPD i FPD. Uroczyste otwarcie pierwszego posiedzenia w IX kadencji miało miejsce 4 listopada $1980 \mathrm{roku}^{40}$. Nowi posłowie do Bundestagu obradowali nad nieco innymi tematami - ich zainteresowania oscylowały głównie wokół pomocy gospodarczej i finansowej dla Polski oraz zagrożenia interwencją ZSRR w Polsce.

Na przełomie listopada i grudnia 1980 roku nasiliły się ostrzeżenia co do możliwości sowieckiej interwencji zbrojnej w PRL. Moskwa coraz bardziej niepokoiła się rozwojem sytuacji po zalegalizowaniu „Solidarności”. Niepokojące było również to, że opinia publiczna krajów zagranicznych otwarcie zastanawiała się, czy dojdzie do interwencji Moskwy. Szczególnie dziennikarze i politycy RFN zakładali zaistnienie takiej sytuacji. Obawiano się, że Moskwa zareaguje podobnie jak w wypadku Węgier w 1956 roku czy w Czechosłowacji w $1968 \mathrm{roku}^{41}$. Artykuły na ten temat drukowano w wielu zachodnioniemieckich gazetach. Poruszano tematy ruchów wojsk sowieckich na polskiej granicy, zagrożenia ze strony ZSRR czy polskich zobowiązań wobec członków Układu Warszawskiego ${ }^{42}$. W prasie zauważalny był niepokój z powodu rozwoju sytuacji w Polsce. „Frankfurter Rundschau” argumentował, że Polska jest państwem utrzymującym powojenną Europę $\mathrm{w}$ równowadze, dlatego cały kontynent jest zaniepokojony. Jeśli więc poddałaby się w pełni komunistycznym naciskom Moskwy, istniała szansa, że ZSRR nie spocznie i będzie dalej rozszerzać swoje wpływy ${ }^{43}$. W „Frankfurter Allgemeine Zeitung” zaznaczono, że ZSRR nie skłoniło się dotychczas do interwencji w Polsce, ponieważ

Rundschau” 19.08.1980; K. Grobe, Die Streikleitung verwehrt niemanden den Zutritt, „Frankfurter Rundschau" 19.08.1980.

39 M. Świder, Bońskie spojrzenie..., s. 231.

40 Exposé inaugurujące nową kadencję 24 listopada 1980 roku wygłosił kanclerz Helmut Schmidt. Przedstawił on program nowego rządu pod hasłem Mut in die Zukunft („,Z odwagą w przyszłość”), w którym nie poświęcono wiele miejsca sprawom PRL. Pojawiło się w nim jedynie zapewnienie o zainteresowaniu sprawą polską, a Schmidt zadeklarował, że RFN nie będzie ingerować w wewnętrzne sprawy Polski. Jeśli jednak rząd polski poprosi o pomoc gospodarczą bądź finansową, wtedy RFN zapewne jej udzieli; zob. Plenarprotokoll 9/5 Sitzung, 24.11.1980, s. 25-41.

41 M. Świder, „Wann werden die Sowjets in Polen einmarschieren?”..., s. 390-391.

42 Washington: Ungewöhnliche Vorkommnisse bei sowjetischen Truppen in Grenznähe, „Frankfurter Allgemeine Zeitung” 27.11.1980; Warnung vor der Armee beendet Streik in Huta, „Die Welt” 29.11.1980; H. Schleicher, Gewehr bei Fuß?, „Frankfurter Rundschau” 2.12.1980.

43 Polnische Leiden, „Frankfurter Rundschau” 13.08.1980. 
strajki polskich robotników nie podważały pozycji partii. Robotnicy, strajkując, bronili jedynie swoich należności i postulatów ${ }^{44}$. Podobnie o sytuacji w Polsce wyrażał się dziennik „Süddeutsche Zeitung”; dodatkowo zwrócono w nim uwagę na zaniepokojenie władz PRL. Polacy znali swoich „przyjaciół” (z bloku wschodniego) i wiedzieli, dlaczego władze były zaniepokojone. Chodziło o obawę, że strajki w Polsce mogły zaważyć na sytuacji w innych krajach bloku wschodniego. Tam również mogło dojść do protestów robotników, to zaś niewątpliwie doprowadziłoby do szybkiej interwencji ${ }^{45}$. Dziennikarz Carl Gustav Ströhm zastawiał się na łamach „Die Welt”, czy nieporadność polskich władz nie zaskutkuje zniecierpliwieniem Moskwy i w konsekwencji jej interwencją w Polsce ${ }^{46}$.

Sprawa interwencji sowieckiej w Polsce poruszana była również podczas wielu spotkań konsultacyjnych państw zachodnich. Przykładami mogą być tutaj spotkania kanclerza Helmuta Schmidta z kanclerzem Austrii Brunonem Kreiskym 24 września 1980 roku czy spotkanie kanclerza z premierem Kanady - Pierreem Trudeau. Omawiano wówczas bieżące problemy w stosunkach międzynarodowych, a także dyskutowano o kwestiach związanych z zaostrzeniem sytuacji w Polsce ${ }^{47}$. Kanclerz Schmidt 10 listopada 1980 roku spotkał się również z prezydentem Francji - Giscardem d'Estaingiem. Celem tychże rozmów było między innymi ustalenie stanowisk RFN i Francji wobec ewentualnej interwencji ZSRR w Polsce oraz omówienie jej negatywnego wpływu na politykę i sytuację Europy. Kwestia interwencji omawiana była ponadto podczas spotkania Schmidta z prezydentem USA Ronaldem Reganem. Kanclerz RFN przekonywał podczas niej, że zagrożenie interwencją nie jest zbyt poważne, ponieważ, jak twierdził, papież Jan Paweł II dobrze wypowiedział się na temat sytuacji w Polsce, a polski episkopat wywierał pozytywny wpływ na Lecha Wałęsę ${ }^{48}$.

Również na forum Bundestagu wyrażano zaniepokojenie sytuacją w Polsce. W mowie rozpoczynającej piąte posiedzenie IX kadencji Bundestagu, 24 listopada 1980 roku, kanclerz Helmut Schmidt zapewniał, że rząd niemiecki śledzi rozwój wydarzeń w PRL $\mathrm{z}$ uwagą i zainteresowaniem ${ }^{49}$. Przy okazji kanclerz wypowiedział się na temat planów zaproszenia przywódcy „Solidarności” do RFN - był przeciwnikiem zaproszenia Lecha Wałęsy do Niemiec, uważał bowiem, że taka wizyta rozdrażni nie tylko władze PRL, lecz przede wszystkim Moskwę. Minister Spraw Zagranicznych Hans-Dietrich Genscher z FDP sądził natomiast, że zajęcie stanowiska w sprawach polskich było nie tylko obowiązkiem zachodnioeuropejskich państw demokratycznych, ale i każdego z państw zaangażowanych $\mathrm{w}$ proces odprężenia ${ }^{50}$. Także Willy Brandt - były kanclerz, wielki autorytet polityczny i szef SPD - wraził swoje nadzieje w stosunku do Polski. Liczył, że kraj ten z walki o swoją tożsamość wyjdzie wzmocniony narodowo, politycznie oraz

\footnotetext{
44 B. Heimrich, Der Sonderfall Polen, „Frankfurter Allgemeine Zeitung” 14.08.1980.

45 Beunruhigendes Polen, „Süddeutsche Zeitung” 21.07.1980.

46 C.G. Ströhm, Kein Ende der Streiks in Polen. Moskau beunruhigt, „Die Welt” 14.08.1980.

47 M. Świder, „Wann werden die Sowjets in Polen einmarschieren?”..., s. 393.

48 M. Świder, Stanowisko Socjaldemokratycznej Partii Niemiec..., s. 162-163.

49 Plenarprotokoll 9/5 Sitzung, 24.11.1980, s. 29.

50 Plenarprotokoll 9/6 Sitzung, 26.11.1980, s. 88.
} 
gospodarczo. Uważał również, że Polacy i Niemcy powinni w nadchodzących latach wspólnymi siłami postarać się o zwalczenie wszelkich konfliktów ${ }^{51}$.

Innego zdania byli posłowie opozycji. Helmut Kohl, szef opozycji parlamentarnej, zauważył, że Polskę czeka ciężka zima, a nowo utworzone wolne związki zawodowe na pewno nie ułatwiają zadania stworzenia nowej politycznej równowagi. Niemniej jednak uznał, że rząd RFN powinien obserwować rozwój wydarzeń z zaangażowaniem i serdeczną sympatią ${ }^{52}$. Natomiast poseł CDU Alfred Dregger skrytykował bezpieczne (to znaczy zdystansowane) podejście RFN do sprawy polskiej. Według niego parlament niemiecki nie powinien wypierać i ideologizować problemu polskiego, lecz odważnie podejść do tematu pomocy i wsparcia tego państwa, ponieważ — jak powiedział — „Jeśli coś nie wychodzi, to nie jest do wina ludu - to wina rządzących" ${ }^{33}$.

\section{Podsumowanie}

Reasumując, należy stwierdzić, że temat Polski na forum Bundestagu w 1980 roku pojawiał się bardzo często. Podczas obrad VIII kadencji poruszano tematy związane z udzielaniem kredytów i polskiego zadłużenia, które niejednokrotnie łączono z kwestiami mniejszości niemieckiej w Polsce. Dyskutowano także na temat losów Niemców mieszkających w PRL, ich praw oraz warunków życia. Ciekawy aspektem obrad były rozważania w zakresie zaleceń dotyczących podręczników historii. Ukazały one niezwykle złożony proces naprawy stosunków polsko-niemieckich po drugiej wojnie światowej.

Widoczny jest rozdział tematyczny między obradami VIII i IX kadencji. Na początku 1980 roku tematyka posiedzeń związana ze sprawami polskimi to przede wszystkim kwestie gospodarcze i mniejszościowe, jednak w momencie eskalacji kryzysu w Polsce zmieniono obiekt zainteresowań. W związku z trudną sytuacją Polaków, nieustającymi strajkami oraz groźbą interwencji ZSRR posłowie zachodnioniemieccy zainteresowali się tą właśnie problematyką. Od listopada zajmowała ona większość debat politycznych, natomiast pozostałe sprawy zostały nieco zapomniane. Podczas posiedzeń głos zabierali posłowie zarówno koalicji rządzącej, jak i opozycji. Szczególnie aktywni w trakcie rozmów na tematy mniejszościowe byli posłowie związani ze Związkiem Wypędzonych, czyli między innymi Herbert Czaja oraz Herbert Hupka. To właśnie ci deputowani niejednokrotnie przypominali, że kwestie pomocy finansowej oraz humanitarnej dla Polski należałoby uzależnić od zagwarantowania większych praw mniejszości niemieckiej mieszkającej w Polsce oraz możliwości dobrowolnego wyjazdu z kraju w każdym momencie.

Politycy koalicji i opozycji nie zgadzali się w wielu kwestiach, a CDU i CSU niejednokrotnie podważały opinie polityków SPD i FPD. Niemniej jednak każda ze stron mogła przedstawić swoje stanowisko i wziąć udział w dyskusji, która miała doprowadzić do wysunięcia konkretnych wniosków.

51 Ibidem, s. 63.

52 Ibidem, s. 47.

53 Plenarprotokoll 9/8 Sitzung, 28.11.1980, s. 238. Tłum. - M.R. 


\section{Bibliografia}

Beunruhigendes Polen, „Süddeutsche Zeitung” 21.07.1980.

Bingen D., Kontinuität und Wandel. Die Bonner Polenpolitik von den Anfangsjahren bis zum Freundschaftsvertrag von 1991, [w:] Erlebte Nachbarschaft. Aspekte der deutsch-polnischen Beeziehungen im 20. Jahrhundert, red. J.P. Barbian, M. Zybura, Wiesbaden 1999.

Bingen D., Ostpolitik und demokratischer Wandel in Mittel- und Osteuropa. Der Testfall Polen, „Archiv für Sozialgeschichte" 45, 2005.

Bingen D., Polityka Republiki Bońskiej wobec Polski. Od Adenauera do Kohla. 1949-1991, Kraków 1997.

Bingen D., Wagner H., Die „deutsche Ostpolitik” in der Sicht ihrer Erfinder, „Rocznik Polsko-Niemiecki” 13, 2005.

Der Deutsche Bundestag im Reichstagsgebäude, red. M. Reinold, Ch. Beinke, Berlin 2007.

Fakten: der Bundestag auf einen Blick, red. H.W. Schors, K. Vogel, Berlin 2006.

Feldkamp M.F., Der Deutsche Bundestag - 100 Fragen und Antworten, Baden-Baden 2009.

Forderungen an die Führung, „Frankfurter Rundschau” 19.08.1980.

Garlicki L., Parlament a rząd w Republice Federalnej Niemiec, Wrocław 1978.

Garlicki L., Ustrój polityczny Republiki Federalnej Niemiec, Warszawa 1985.

Gierek: Wir haben Fehler gemacht. Treffen mit Kanzler Schmidt abgesagt, „Rheinische Post” 19.08.1980.

Gierek in Not, „General-Anzeiger” 19.08.1980.

Grobe K., Die Streikleitung verwehrt niemanden den Zutritt, „Frankfurter Rundschau” 19.08.1980.

Heimrich B., Der Sonderfall Polen, „Frankfurter Allgemeine Zeitung” 14.08.1980.

Isensee J., Kirchhof P., Parlament Republiki Federalnej Niemiec, Warszawa 1995.

Ismayr W., Der Deutsche Bundestag. Funktionen, Willensbildung, Reformansätze, Wiesbaden 2012.

Ismayr W., Der Deutsche Bundestag im politischen System der Bundesrepublik Deutschland, Opladen 2000.

Jackowska N., Układ z 1970 roku o podstawach normalizacji stosunków z RFN: przypadek ponadpolitycznej zgody?, „Studia Politologica” 5, 2011, s. 144-157.

Kaiser C., Kessel W., Deutscher Bundestag 1949-1999, München 1999.

Klepacka J., Wspólna przeszłość - wspólny podręcznik?, „Polski Kalendarz Europejski” 2009, nr 123.

Der Konferenz-Trick, „Frankfurter Allgemeine Zeitung” 13.02.1980.

Madajczyk P., Marzenie o narodzie doskonałym. Między biopolityka a etnopolityka, Warszawa 2017.

Madajczyk P., Na drodze do pojednania: wokół orędzia biskupów polskich do biskupów niemieckich z 1965 roku, Warszawa 1994.

Madajczyk P., Niemcy polscy 1944-1989, Warszawa 2001.

Mołdawa T., Ludzie władzy 1944-1991, Warszawa 1991.

Otto Graf Lambsdorff gestorben, https://www.welt.de/politik/article5442764/Otto-Graf-Lambsdorff-gestorben.html.

Polnische Leiden, „Frankfurter Rundschau” 13.08.1980.

Protokoły plenarne obrad Bundestagu VIII i IX kadencji (styczeń 1980-grudzień 1980), https://www.bundestag.de/protokolle.

Riedmiller J., Edward Giereks neue Abrüstungs-Offerte, „Süddeutsche Zeitung” 13.02.1980.

Ruchniewicz K., Enno Meyer a Polska i Polacy (1939-1990). Z badań nad początkami Wspólnej Komisji Podręcznikowej PRL-RFN, Wrocław 1994.

Schick R., Zeh W., So arbeitet der deutsche Bundestag: Organisation und Arbeitsweise. Die Gesetzgebung des Bundes, Bad Honnef 1999.

Schleicher H., Gewehr bei Fuß?, „Frankfurter Rundschau” 2.12.1980.

Schröder D., Machtprobe mit Gierek, „Süddeutsche Zeitung” 19.08.1980.

Skodlarski J., Zarys historii gospodarczej Polski, Warszawa 2000.

Solidarność związkowa. Niemiecka Federacja Związków Zawodowych (DGB) wobec NSZZ „Solidarność”, wybór, wstęp i oprac. M. Świder, Kraków 2017.

Sowa A., Historia polityczna Polski 1944-1991, Kraków 2011. 
Stalmann V., Die FDP-Fraktion im Deutschen Bundestag, Düsseldorf 2017.

Streiks in Polen - gegen die Partei, „Der Spiegel” 18.08.1980.

Ströhm C.G., Kein Ende der Streiks in Polen. Moskau beunruhigt, „Die Welt” 14.08.1980.

Ströhm C.G., Parteitag der Surrealisten, „Die Welt” 13.02.1980.

Świder M., Bońskie spojrzenie na polski sierpień, [w:] Czas Przełomu. Solidarność 1980-1981, red. W. Polak, P. Ruchlewski, V. Kmiecik, J. Kufel, Gdańsk 2010.

Świder M., Oficjalne deklaracje i zakulisowe gry. Problem mniejszości niemieckiej w Polsce pod koniec lat osiemdziesiątych, [w:] Upadek systemu komunistycznego na Górnym Śląsku. Wokót przemian 1989 roku w województwach katowickim i opolskim, red. A. Dziuba, S. Rosenbaum, Katowice 2010.

Świder M., Sierpień 1980 - zaskoczenie czy spodziewany wybuch? Konflikt społeczno-polityczny w Polsce w ocenach dziennikarzy zachodnioniemieckich, „Studia Zachodnie” 2010, nr 12.

Świder M., Stanowisko Socjaldemokratycznej Partii Niemiec wobec Polski w latach 1980-1989, Opole 2015.

Świder M., „Wann werden die Sowjets in Polen einmarschieren?”. O groźbie interwencji sowieckiej w Polsce 19801982. Widziane z Bonn, [w:] O Polskę wolną! O Polskę solidarną! NSZZ Solidarność w latach 1980-1989, red. W. Polak, S. Galij-Skarbińska, V. Kmiecik, M. Białkowski, J. Kufel, P. Ruchlewski, Gdańsk 2011.

Świder M., Wpływ polskiego sierpnia na niemiecki październik 1980 roku, [w:] Trudne sasiedztwo. Z dziejów relacji polsko-niemieckich w XX i początkach XXI wieku, red. K. Jedynakiewicz-Mróz, Wrocław 2011.

Trzcielińska-Polus A., Pomoc RFN dla Polski i Polaków w latach 1980-1983 (na podstawie dokumentów Bundestagu IX kadencji), [w:] Polityka i humanitaryzm. 1980-1989, red. M. Świder, Toruń 2010.

Trzcielińska-Polus A., Polska na forum Bundestagu (1990-2002). Współkształtowanie przez Parlament Związkowy polityki zagranicznej Niemiec w kontekście procesu integracji europejskiej, Opole 2008.

Trzcielińska-Polus A., Współkształtowanie polityki zagranicznej Niemiec przez Bundestag, [w:] Polityka zagraniczna zjednoczonych Niemiec: kontynuacja czy zmiana?, red. I.P. Karolewski, Wrocław 2011.

Vorsichtiger Vorstoß, „Frankfurter Rundschau” 13.02.1980.

Warnung vor der Armee beendet Streik in Huta, „Die Welt” 29.11.1980.

Washington: Ungewöhnliche Vorkommnisse bei sowjetischen Truppen in Grenznähe, „Frankfurter Allgemeine Zeitung" 27.11.1980.

Wojtaszczyk K.A., Bundestag i Bundesrat w Republice Federalnej Niemiec, Warszawa 1993.

Wolff-Powęska A., Doktryna geopolityki w Niemczech, Poznań 1979.

Wolff-Powęska A., Polacy wobec Niemców. Z dziejów kultury politycznej Polskiej Rzeczypospolitej Ludowej 1945-1989, Poznań 1993.

Wolff-Powęska A., Polen in Deutschland: Integration oder Separation?, Düsseldorf 2000.

Zalecenia Komisji UNESCO Polskiej Rzeczypospolitej Ludowej i Republiki Federalnej Niemiec do spraw Podręczników Szkolnych w Zakresie Historii i Geografii, http://deutsch-polnische.schulbuchkommission.de/ fileadmin/_dpsk/Bild/Zaleceni_1972.pdf.

Zuspitzung in Polen, „Der Tagesspiegel” 19.08.1980.

\section{The Polish crisis on the Bundestag forum in the 1980s}

Keywords: Bundestag, Polish-German relations, 8th and 9th term, credits, German minority, crisis

Summary

In the summer of 1980 a period of rapid social changes began in Poland, which became the subject of observation, analysis and discussion in many European countries. In the Federal Republic of Germany, the subject of Poland and the emerging economic crisis was discussed in the Bundestag. The aim of this article is to answer the question about the subject matter and intensity of Polish issues at the forum of German parliaments. How was the situation on the Vistula River reported? Who spoke most often and what demands did he make? Was the democratization of political life in Poland believed in? The author examined documents from the plenary sittings of the Bundestag held from midsummer until the end of December 1980. 